\title{
CEO’s And Managerialism, Success Trap, Blind Trust, And Global Mindset: Introducing The Individual Vigilance/Social Experimentation Framework
}

\author{
Jacqueline Fendt, (Email: J@jaygroup.ch), ESCP-EAP European School of Management, France
}

\begin{abstract}
This ten-year empirical study explores the nature of Chief Executive (CEO) leadership and coping in post-merger situations. Executives' need to manage multiple organizational realities and various groups of internal and external stakeholders, often representing conflicting interests, whereby four separate albeit interrelated concepts come into play, namely managerialism (vs. leadership), the liabilities of success (success trap), excess of trust (blind trust) and global mindset. The paper purports that these concepts can be understood as functions of the degree of individual vigilance and social experimentation that a leader applies to the task at hand and introduces the individual vigilance/social experimentation framework.
\end{abstract}

\section{INTRODUCTION}

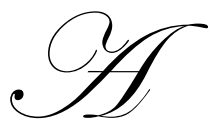

global business environment characterized by liberalization, consolidation and convergence, by acceleration of time to market and by the war for talent, for knowledge and for customer fidelity sets a challenging agenda for corporations and their leaders. Furthermore, ever more sophisticated information and communication technologies (ICT) heighten market players' exigencies (Rüegg-Stürm and Achtenhagen, 2001). Leaders must manage high complexity and ephemeral structures, make proof of flexibility and strong adaptation skills (Fulmer, 2000), of anticipation (Schwager and Haar, 1996) and strong communication (Von Wartburg, 1999, 2004). As a reaction to and in anticipation of this increased complexity and the pressures for growth, corporations tend to reinvent themselves (Ruigrok et al, 1999: 39) and develop new forms of organizations such as mergers, acquisitions (Schuler and Jackson, 2001: 239) and strategic alliances (Jackson and Schuler, 2002; Schuler and Jackson, 2002), or also the outsourcing of secondary processes, network organizations and virtual teams (Chesbrough and Teece, 1996; Lipnack and Stamps, 1998). Mergers and acquisitions (M\&A), as is widely referenced, mostly do not achieve their expected objectives (e.g. Charman, 1998; Grubb and Lamb, 2001; Hussey, 2002; Keite, 2001; Watson Wyatt, 2000) and often result in considerable financial, strategic and emotional damage (Child et al, 2001; Galpin and Herndorn, 2001). Academics and practitioners have found that the difficulty in combining corporations lies less with identifying optimal strategic fit than with implementation during the post-merger phases (Goleman, 1999; Green, 2004; Hubbard, 1999). In four decades of abundant M\&A practice and despite considerable theoretical concern, this issue is not improving. Whatever strategic or financial key figures researchers track, findings persistently yield that around two thirds of all M\&A that fail to create shareholder value (Ashkenas and Francis, 2000; Sirower, 1998; UNCTAD, 2003). Among the principal reasons for failure, the human dimension, i.e. the inability to lead a process that reconciles the multiple stakeholders' conflicting values and beliefs in the post-merger phase, ranks highest (Buono et al, 1985; Croyle and Kager, 2002; Farmer, 1996; Fortgang et al, 2003; Krug, 2003; Mosher and Pollack, 1995; Sitkin and Pablo, 2005; Von Wartburg, 1999, 2004). Moreover there is evidence that even actors with antecedent M\&A experience do not imperatively perform better (Haleblian and Finkelstein, 1999: 30; Srikanth, 2005; Zollo and Reuer, 2001). This paper looks at the top executive's leadership in relation with post-merger success, with special focus on the concepts of managerialism, success, trust, and global mindset. 


\section{THEORETICAL AND EMPIRICAL FOUNDATIONS AND METHODOLOGY}

This paper is based on data accumulated during a ten-year PhD project on how CEOs - here leaders of Swiss or German-based global corporations - cope with the demands placed on them during post-merger integration. The original study is grounded in a broad review of relevant theory (leadership, M\&A, power theory, knowledge management, andragogy, change management, and human resources management) and vast documentary evidence and includes two major sources of empirical evidence. The researcher was herself a leading executive and in this capacity had extensive contacts with the business elite of her region. She kept detailed professional notes and in the original study distilled it into ethnographic-style tales (Van Maanen, 1988), illustrating various facets of the mergers and acquisition game. The tales narrated the leadership of six CEOs in high-tension transient situations over a period of several years, namely:

- $\quad$ A CEO is called into a global banking merger in which a secretive, hierarchical, and somewhat arrogant culture reigns. He attempts a radical cultural change toward an open, team-based, and entrepreneurial culture and becomes the icon of this change. The merged organization goes through a severe leadership crisis that leads to the stepping down of the CEO - while the object of change (more transparency; open, risk-taking culture) remains valid and the merger develops very successfully.

- $\quad$ A leader of a highly reputed European airline chooses an aggressive growth strategy and multiplies mergers and acquisitions. His board is composed of the most reputed executives of the country and he is seconded by the best business consultants available. The mergers derail completely due to intercultural conflicts, resistance and the company ends up in receivership.

- $\quad$ A German CEO initiates a large, spectacular transatlantic automotive "merger of equals" that results in massive jobs annihilation, an important reduction of shareholder value and, quickly, the US merging partner is reduced to a mere subsidiary.

- A sequence of several taxing and partly undigested mergers in the IT industry with substantial restructuring, layoffs, etc. result in depression and burn out of one of the country managers and strong demotivation of the rank and file.

- $\quad$ A CEO with a reputation for mercilessly restructuring companies in difficulty is called in to take on a merger of a global technology firm with a chip manufacturer. Due to his success, the chairman is called to the boards of several other firms and ended up dissipating his energies. One by one, the companies experienced major crises. Under heavy media criticism the chairman was forced into early retirement.

- $\quad$ A young and brilliant but relatively inexperienced CEO is appointed to perform a giant and tough global merger of two traditional Swiss-based life sciences groups. Despite the fact that the CEO has no merger experience and no lobby in the company or industry, he leads the merger quickly and remarkably smoothly to sustainable success.

Grounded in this experience, the researcher then conducted a second research loop that involved ten case studies of major global corporations that had been involved in significant acquisitions or mergers since 1996. The backbones for each case are four in-depth, narrative interviews, two with the CEO and two with a close member of his (no hers were involved) management team, each interview pair conducted with an interval of between 6 and 18 months. Interview transcripts were subjected to formal content analysis, with validation by both the respondents and a second researcher. In a constructionist Grounded Theory process (Charmaz, 2000, 2006; Goulding, 2002) this extensive data was abstracted.

The original study did not set out to look in particular for the discussed concepts of managerialism, success trap, excess of trust or global mindset. But the results that emerged showed that these concepts played a key role and the desire to analyze them and their interrelation further led to this paper. Mergers are environments of very high stress: cultures collide; established rules, relationships of trust and comfortable positions are upset, anxiety and com- 
petition is high, and so is the temptation to manipulate or obfuscate information. The CEO is shelled with urgent problems and pulled in all manner of directions by opposing forces. Multiple personal and organizational dilemmi have to be dealt with simultaneously in a multitude of new contexts and frequently well across unit boundaries and organizational levels. The research has observed how leaders ran apparently successful organizations into disaster and how others saved them from just that and brought them back on track. Every time, sound strategic and financial decisions were necessary. But to successfully manage change, leaders needed to do more than that. Rather than manage an organization they had to win the trust of their internal and external stakeholders by demonstrating that the direction proposed makes sense (Kouzes and Posner, 1987).

\section{FINDINGS}

Abstraction of data has yielded seven concepts of managerial behavior, namely:

- $\quad$ The Executive Self

- $\quad$ Searching for Truth

- $\quad$ Searching for Knowledge

- $\quad$ Understanding Culture

- $\quad$ Searching for Performance

- $\quad$ Searching for Bonding

- $\quad$ The Post-Merger Environment

These concepts are not standalone codes but have properties and dimension that are explained and abundantly mirrored with extant theory in detail in the original study. For better understanding of the research process these concepts are summarized in Figure 1 (see next page).

From these concepts have emerged four separate and yet interrelated phenomena, which are the object of this paper and are presented below, namely

- $\quad$ Managerialism (vs. leadership)

- $\quad$ The dangers of success (success trap)

- $\quad$ Excess of trust (blind trust)

- $\quad$ Global mindset

\section{MANAGERIALISM VS. LEADERSHIP}

The CEO in the technology merger had had a brilliant and highly successful management career. As long as he had taken on and managed companies in deep trouble his astute managerialist ${ }^{i}$ skills and strictly facts-and-figuresfocused attitude worked perfectly: when employees have the choice between bankruptcy and a hierarchical mechanistic work environment the choice is quickly made. However, in his last assignment, the researched merger, the situation was different in that he had to merger two companies that were in excellent shape and were endowed with managers and staff of excellent quality and self-confidence. Here, his management style based on an "... almost technocratic belief in systems and procedures" (Fendt, 2005) was clearly insufficient. Similarly, the CEOs of the automotive and the airline mergers focused their activities largely on results and ignored by and large the human processes involved to achieve them.

- I'm a results guy in the end. That's what gets measured." CEO Respondent

- "Our CEO is not around enough. We're always short of time with him (...) there were times in the merger aftermath that he spoke to me through the media more than in person." CFO respondent about his CEO

- $\quad$ "I sometimes feel uncomfortable with the decisions we make (...) our CEO is traveling permanently (...) He wants to be present everywhere and paradoxically it feels as if he were present nowhere. HR manager about his CEO 
- II'm impatient. Very impatient. I hate slow people and processes. I'm an impossible person in this respect." CEO respondent

- $\quad$ "Our CEO is a one-track-mind. Figures. Results. At least you know where you're at." CMO respondent about his CEO.

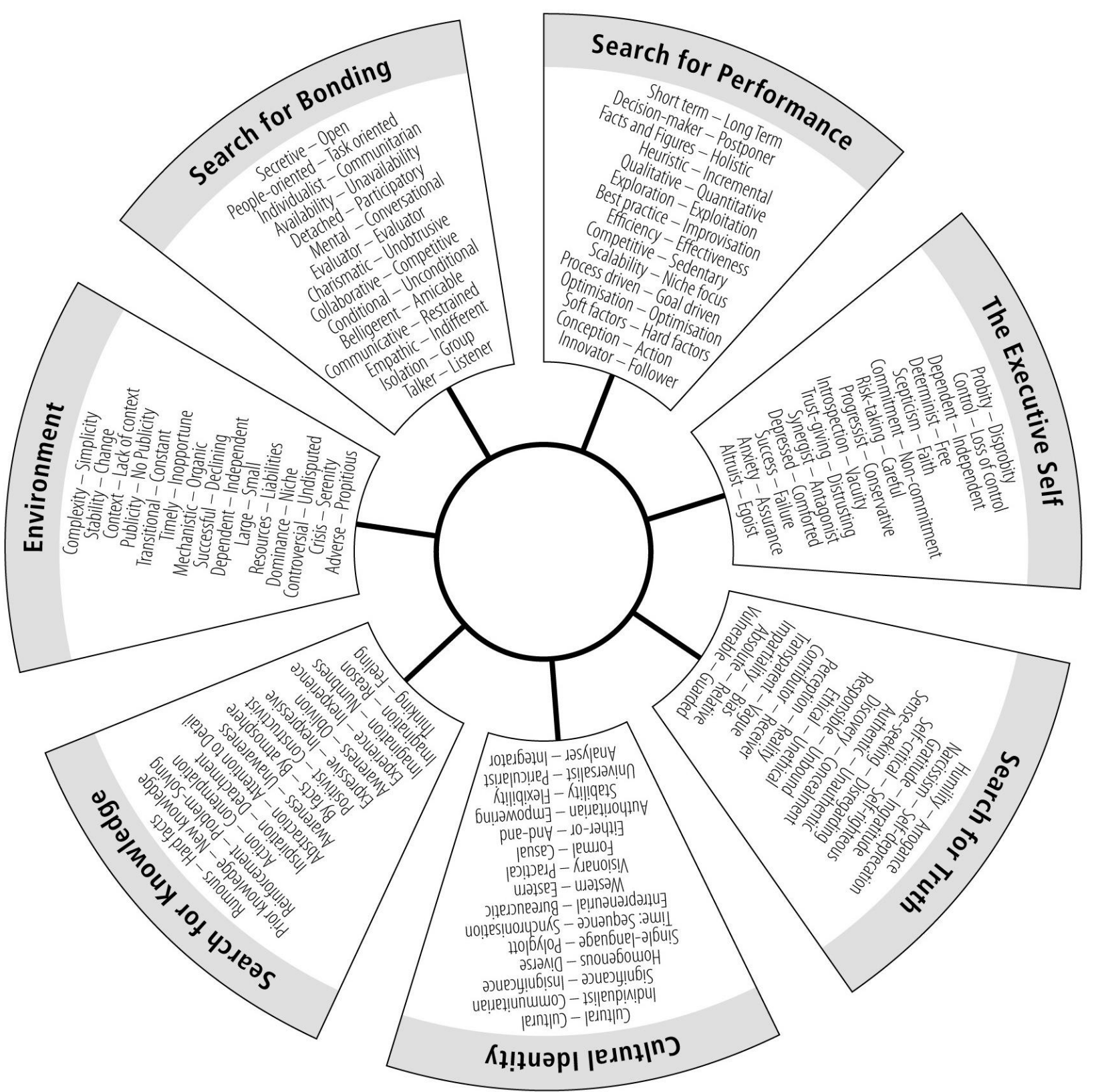

Figure 1: Concepts Of Executive Behavior And Their Properties And Dimensions 
The literature on management and/vs. leadership is abundant. The term management basically encompasses the technological, analytical, structured, controlled, and deliberate side of a CEO's tasks, whereas leadership focuses on the psychological and sociological qualities, such as experimentation, vision, flexibility, creativity, intuition and communication (Hickman, 1990). These concepts are seen in the literature as interdependent and complementary, management being concerned with the 'hard' and technological issues of bringing an organization to perform, while leadership encompassing the soft side of business, the people aspects. Some scholars see the concepts of management and leadership as incremental: "Management becomes leadership when a leap of faith on the part of the followers is required to move them in the desired direction. Management is logical; leadership goes beyond logic. (...), Leadership [is management] with ethics and values in such a way that the practice becomes systematizes, sustainable and transferable (Heames and Service, 2003; Weaver, 2004). Some authors see the concepts of management and leadership as exclusive. Kotter (1990) postulates that they are different systems of action involving the same functions - e. g. decide what must be done, create the structures and processes that can organize the resources toward what must be done and ensuring that people actually do what must be done - but accomplish them in different ways (Hunt and Scanlon, 1999; IHM Research Update, 1003; Kotter, 1990).

There was strong evidence from the research data that organizational outcomes, both strategic and operational, are reflections of the values and cognitions of powerful actors in the organization (Hambrick and Mason, 1984; House and Aditya, 1997). Yet a substantial body of literature, especially in the field of strategic management, explains organizational strategy and effectiveness as detached from people and centers on techno-economic factors (Hambrick et al., 1982; Pfeffer, 1977). Many respondents were strongly management-oriented. They were excellent planners and budgeters. They set targets and goals, allocated resources to their plans, organized and staffed. But many did not sufficiently 'set a direction'. Planning is deductive in nature and designed to produce results, setting a direction is destined to produce change. It requires a holistic viewpoint, it involves cultural aspects, looking for patterns, linkages and relationships in the data at hand that can provide explanation of why the plan - in the case of a merger the proposed future - is good for the company and which are the steps that could lead to it. By this, those who can create coalitions are aligned and committed to goal, which has become common. Since many of the success factors in post-merger management are people-based and prone to extreme power play the need for complementing management with leadership is enhanced: "A peacetime army can usually survive with good administration and management up and down the hierarchy (...). A wartime army, however, needs competent leadership (...), No one yet has figured out how to manage people effectively into battle; they must be led (Kotter, 1990)". The traditional, managerialist management style of organizing, directing and controlling proved to be starkly inadequate for culture integration tasks. The technology CEO soon reached the limits of his management style, just as the leaders in the automotive and the airline mergers. The need to link facts and targets to a certain extent to human needs, values, and emotions is not a new insight. Yet examples of it being truly practiced by the researched top executives, rather than just claimed in the human resources section of annual reports, websites and memoranda were rare. It seems that in post-merger situations, perhaps for the sake of speeding up the process, the leadership part of executive action is often diminished rather than accentuated. But post-merger leadership seems to involve an enhanced need for individual vigilance and, simultaneously and paradoxically, for social experimentation, a behavior described here in some more detail as the ability to see, to think, to feel, to know, to act and to learn differently:

- To See (Intentionally, Purposely): For one, many respondents simply did not see the need to “...bridge the chasm of cultural differences (Shelton, 1999)". They remained in their hitherto successful stereotype behavior and were unable to 'see intentionally' to focus on those aspects that support the objective of integration (Shelton et al., 2003: 318). Intention, the psychological process that creates reality, i.e. the human perspective thereof (Csikszentmihalyi, 1990: 27), directs attention to certain stimuli and ignores the multitude of other perceptual options. Once this attention is obtained, there is a disposition to continue noticing the same stimuli and perception becomes repetitive and habitual (Shelton and Darling, 2001: 266). But intentional seeing also enables managers to break free from stereotypes and consciously select new intentions. Had the respondents understood this, they would have involved all the stakeholders in a process of vision creation for the new organization. Like this, they were incapable of seeing and therefore of creating a new organizational reality. Instead the old reality was being destroyed but not replaced by a new one, thus creating tremendous frustration and resistance. One respondent, the CEO of the global life sciences merger, displayed the behavior of inten- 
tional seeing. His example evidenced how clear intention among the stakeholders strongly facilitates target achievement (Rosenberg, 1998; Shelton et al., 2003).

- $\quad$ To Think Beyond The Box: The respondents were all brilliant, intelligent, and previously successful executives, but at a certain point in time many failed to think 'outside the box' (Chussil, 2005). They stuck to their models that had worked in the past and when difficulties arose, they attributed them to inaccurate data being fed into the model rather than to the structure of the model (Chussil, 2005). This blockage on hitherto successful models in new situations could be observed in many cases: a great number of CEOs enhanced the same action when in difficulty rather than changing their tactic. Such cognitive stereotypes are also described in learning theory, namely by Argyris and Schön (Argyris, 1994; Argyris and Schön, 1978), who call this behavior 'single loop learning' and suggest that learning should be lifted to a higher level, dubbed 'double-loop learning', in which policies, norms and models are also challenged, rather than just the specific error in question. Similar cognitive behavior is described by Levinthal and March (1993), there dubbed the 'success trap', stipulating that when executives have repeatedly successfully coped with their environments they tend to interpret this as a rationale for institutionalized cognitive models on organizational structure, practice and logic and padlock themselves to new learning, while the environment continues to change. Successful merger leaders, such as the life sciences CEO, seem to be allow for more deviance in their thinking (McKenzie, 2004) and are thereby more capable of discarding accepted methods and recognizing and using different models in different situations (Shelton, et al., 2003). They understand that mergers are paradoxical situations and that less is sometimes more and slower is sometimes faster and that merger results are often a function of critical relationships rather than critical mass (Handy, 1998: 107). The life sciences CEO had radically changed his organization and assured that major synergies were achieved, but he also understood the power of small units. For example, he had observed the fact that small upstarts would always beat his company in research and development. Small units are more entrepreneurial: they are intelligent in strategy formulation (Chussil, 2005), more flexible in their reaction to the markets and align corporate and personal goals better (Colvin, 2001; Gladwell, 2002; Semler, 1993). So he tried to beat the odds by creating small units within his big corporation to have the best of both worlds. There are other examples of executives (not from this research) who had successfully managed to be 'big and small' at the same time: Bill Gore of Gore Associates, had introduced the 'rule of 150' in his company, meaning that each facility was to be limited to 150 associates. Thus his company could grow, and did, yet continue to behave like small entrepreneurial start-ups. Semco had a similar strategy. The company grew over $20 \%$ per annum over more than a decade but did not have headquarter facilities or even an organigram. Most respondents in this research on the other hand had created situations where the merging partners actually blocked each other, not only in operations but also in the markets. What seems to be common sense, namely exploiting the natural strengths of the organizations at hand, appeared to dictate a need for paradoxical thinking (Courtney, 2003; Shelton et al., 2003).

- $\quad$ To Dare To Feel: The heart is the primary source of energy for the mind-body system (IHM Research Update, 1993). It generates signals that are a function of thoughts and emotions. Positive emotions such as joy, hope, and love increase coherence and thus energy. Negative emotions such as anxiety, frustration, anger, conflict and stress decrease coherence and cause the mind-body system to lose energy (Shelton and Darling, 2001; Shelton et al., 2003: 319). The heart 'calculates' the ratio of positive to negative emotion and determines thus our sense of wellbeing (Diener and Larsen, 1993; Goleman, 1995: 63). Many of the researched mergers were principally stress-filled and proved to be a major energy drain as evidenced by the executives' own accounts and by the defection of so many key executives. It seems therefore important to create a climate that makes people feel alive and energized, regardless of external circumstances: a climate of appreciation and encouragement, rather than a problem-focused leadership style. To begin with, this requires a CEO who recognizes the stake that relationships and emotions play in a merger environment (Hunt and Scanlon, 1999; Krass, 1998; Willingham, 1997). For this, he or she should be capable to express emotions to a certain extent. The leadership of most researched protagonists was devoid of any visible emotional component. They seemed to have some psychological awareness of the above concept, because in their organizations certain negative words, for example the word 'problem', were banned from the corporate management vocabulary and replaced by others, for example 'challenge'. But since there was a discrepancy between the imposed psychological rhetoric and the rationality of the leaders, these measures turned sour and followers became cyni- 
cal about them, which they expressed with such comments as "'Synergies'...I can't hear it anymore", or also "Marriage of equals... it feels more like a shotgun marriage to me". One leader, the IT CEO had strong emotional intelligence in his earlier executive years but lost it in the taxing process that led him into burn out. The banking CEO had acknowledged the emotional side of his management, he was sociable and affective, but lacked some other social skills that would have allowed him to get his colleagues to cooperate in the direction he desired (Goleman, 1995). Moreover, his collegial attitude was in such stark contrast with what his followers had been used to before that it was not trusted. The life sciences CEO's leadership was a strange mix of emotionality and rationality: "I needed to be both empathically and perfectly callous, outright impassible. It's a paradox: on the one hand, regarding the individual fate, you must have compassion, you must care to find good solutions - but where the whole organism is concerned, you must proceed in a swift, cold, and rational manner". He worked a lot with empathy and aligned people by taking into account their feelings and by an exceptional cross-cultural interest and sensibility, which he also proved by speaking at least three languages perfectly. He displayed much self-awareness, which other leaders did not display. He was conscious of his weaknesses and not afraid to talk about them, a candor that in the automotive leader's organization would have been mistaken for 'wimpiness', as some German executives commented the tears the US CEO had once shed during a management meeting at the height of the merger in-fighting. But the life sciences CEO's self-awareness was accompanied by a capacity for self-regulation, permitting him to control impulses or even channel them toward good purposes (Goleman, 1995, 1998).

- To Know Intuitively: The over-abundance of data available in the information age mandates new ways of dealing with information. Many CEOs relied much on data analysis techniques, linear forecasting and strategic planning methods, which were inadequate in these transient, complex and non-linear organizations. Intuitive decision-making processes played an increasingly important role: "Intuition is neither a conscious rational process nor a linear exercise (...). The ability to scan large amounts of information without a predetermined agenda, and yet be able to tap that subconscious trove of possibly pertinent data, may become the only way that the managers of the next century will be able to keep ahead of competition" (Black, 2000; Parikh, 1994).

- To Act Ethically: In the researched transient situations, executive action was often observed more closely than in more stable situations. To begin with, each stakeholder's contract - legal and/or moral - with any one of the previous companies was jeopardized. Drastic change was announced, confusion reigned, and there were bound to be winners and losers among the stakeholders involved. Moreover, because of the interconnectedness of the systems, each executive decision influenced other stakeholders' decisions as well (Rosenberg, 1998). Often the merger aroused important media attention, which enhanced the visibility of executive action even more. To act ethically and responsibly was essential - both in the sense of 'action', i.e. of making good, ethical decisions that help the organization to perform to the benefit of all stakeholders, as also in the sense of 'actor', i.e. to step up onto the scene to communicate and inform clearly and responsibly what is happening. Hooijberg and Quinn (1992) speak of: “...the ability to act out a cognitively complex strategy by playing multiple, even competing roles in a highly integrated and complementary way." For example, the technology CEO was a silent, rational decision-maker. Throughout his career, as long as he had been in environments that were doomed before his arrival, this hierarchic and occlusive behavior was functioning. But at his latest assignment, the technology merger, things were different. That group was in reasonable shape and the stakeholders had enough self-esteem to dare to question and even resist decisions. The CEO was unable to understand this difference in context and assume this new role of negotiation and transparency.

To Learn, To Cope: Remaining vigilant to and capable of adapting to changing environments is described as a key requirement for survival (Fligstein, 1990; Pfeffer and Salancik, 1978; Schein, 1996, 1996a, 1997; Senge, 1990, 1998). In merger situations "the situation changes every day" as one respondent put it: key executives leave, existential contractual liabilities that the due diligence process had not identified are unearthed, unions call for walkouts, key customers defect, majority shareholders sell their shares, media bashing sets in on some detail which grows into a major scandal and many more such surprises expect the CEO when he or she gets to the office in he morning. Imperfect information is therefore acknowledged as a fatality and experiential learning tends to replace long-range planning and rational calculation as bases for organiza- 
tional survival (Huber, 1996; Levitt and March, 1988). Experience, however, is not always a good teacher and some of the cognitive limits that constrain rationality can also constrain learning. When executives had repeatedly successfully coped with their environments they tend to interpret this as a rationale for institutionalized cognitive models on organizational structure, practice and logic and padlock themselves to new learning, while the environment continues to change (Askvik and Espedahl, 2002). Levinthal and March call this phenomenon the 'success trap' (1993). It is the consequence of “....mutual local feedback between experience and competence. (March, 1994: 38)".

\section{THE DANGERS OF SUCCESS}

The 'success trap' (Levinthal and March, 1993) was a much observed phenomenon observed in the research. CEOs often settled in a specific area in which they had competence and generalized from that position. This generalization is at first positive, as experiences are often similar to antecedent ones. Often, the antecedent success was at the origin of the new assignment. As a consequence of the successful exploitation of a particular action and behavioral strategy the executive's confidence is often boosted to an overrated extent. And by generalizing their experience to other areas they were then prone to exaggerating the likelihood of success. But this may not be thus if the new area and/or contexts are significantly different (Srikanth, 2005; Zollo and Reuer, 2001), and indeed it was not. Yet, as long as confidence is boosted, often also by an adulating business press, executives: “... will tend not to discover and not learn from a number of unanticipated failures when these are insignificant (Askvik and Espedahl, 2002: 6)". The following liabilities or dangers of success were identified in this research:

- $\quad$ Complacency: Executives were unlikely to experiment with ideas when they were confirmed with existing models that perform successfully. When the period of success was long, the refusal to leave existing routines persisted even in the face of some alarming or disruptive events occurring. This was especially so, since, as could be observed in the case studies, there often is a time lag between the problems arising in the organization and stakeholder criticism. A CEO's reputation (and thereby his external feedback) may still be at its peak while he is already facing serious problems within the organization.

- Isolation, Homogenous Contacts: Many CEOs surrounded themselves with people similar to them and did not have satisfactory internal feedback at their disposal: "One of the greatest dangers of positions of power is isolation. It's almost a law of nature." CEO respondent. "Homogeneity is almost a credo [in our top management team]... there's a sort of 'sample type' and they want him cloned by the dozen if possible...No diversity culture at all." HR Manager about his top management team. "My boss tends to choose his alter ego when he fills a new post." HR Manager about his CEO. For a certain period of time, the CEO that is facing new challenges is therefore exclusively dependent on his own vigilance and critical reflection capacity. It is only when disruptive events are becoming visible as such that the feedback begins to exert pressure on the executive and assist him, possibly, to leave existing routines.

- $\quad$ Risk: To experiment while the going is good may be risky since the experimentation may result in something unsuccessful and the executive may lose face and/or be reprimanded by the Board or the media for not adhering to procedures. Executives therefore tended to wait until the 'risk of not experimenting' became visibly superior to the risk of experimenting.

- Information Blinker: Success tended to limit the attention to and search for data that might have tergiversated some of the anticipated and presumed positive results. In many cases priority was given to data supporting existing routines. Only in the life sciences case the CEO was described by his executives and other stakeholders as keeping vigilant and an open mind, "... also and especially when the going is good".

- Homogeneity, "Pensée Unique": Success fostered homogeneity and uniformity regarding procedures, staff and culture. As long as successful, the CEOs would strive to maintain their successful formula by avoiding divergent actions and by keeping practices uniform. This led to 'groupthink', to one, the only, way of thinking in the organization. This again had an influence on the executives' choice of team members, which were mostly from one merging company and often, as stated, their clones. This homogeneity subsequently fur- 
thered conservatism and anti-experimentalism attitudes within the organizations' management teams and pushed any experimentation willing individuals out of the team (Askvik and Espedahl, 2002: 7; Sitkin, 1992).

The literature interprets learning limitations as cognitive due to 'finite information processing capacity' experienced by executives in the face of ambiguity, conflict and uncertainty (Vaara, 2003). But there may be other explanations, especially in post-merger situations. Successful executives developed biases with regard to how they came to consider action and evaluated the results of their action. At all moments, companies develop 'world views' (Hedberg, 1981:8), i.e. collective interpretations of their reality. They blazon these views with epic narration and images of themselves and their environment. These views, called 'strategic paradigms', are bundles of rules and norms used for meaning and sense making, which influence which issues are perceived and how they are perceived and what learning and collective interpretation of organizations ultimately results. The strategic paradigm is shaped by information the management team receives from internal and external sources and inversely the strategic paradigm will itself shape the way this information is collected and interpreted. "It affects the actors' perception of what is happening, why it is happening and whether what happened was satisfactory. In this way the strategic paradigm constructs socially approved conceptions of legitimate organizational practices, and that again might give the actors a conception of control (Askvik and Espedahl, 2002: 9)." In addition to the cognitive limitations to learning described in the literature, there were also political limitations, in general but especially in post-merger situations where the stakes and the ambiguity were high and the cards were being shuffled anew for the winners and losers to be determined. According to Cyert and March, this game is played by multiple stakeholders with conflicting interests not entirely solved by organizational rules (1963) and instances of conflict and interest competition are determined by power relations. These stakeholders' will be affected by how problems are addressed by top management and, consequently, a multitude of organizational games of interests and power, mediated by the frameworks the organization uses to comprehend its environment might evolve around the strategic paradigm (Askvik and Espedahl, 2002; Mintzberg, 1983, 1984, 1985; Pfeffer, 1981, 1982). In the technology CEO's case a military background was identified as an asset for career promotion, the banking CEO insisted on risk taking as a critical component, the airline CEO had set his priorities on rational, figuresdriven executives and in the automotive leader's world it was good to be German and an engineer, whereas in the US merger partner it was entrepreneurship and sales that counted. Those who disposed of these qualities and functions benefited from these respective frameworks in status and resources. It can therefore be argued that executives who have vested interests in certain frameworks rather than others will tend to favor strategic diagnosis and action that promotes these interests. Denial of problems and crisis may arise from sincere albeit ignorant conviction but it can also arise from resistance in order to retain or obtain power and status. In post-merger situations these 'paradigm politics', where conflicting perspectives are disseminated by opposing stakeholders (Starbuck et al., 1978: 118) are much more intense and create strong disruption in the internal and external communication of the organization (Argyris, 1994). CEOs countersteer this by developing 'defensive routines' that prevent stakeholders from experiencing face loss or threats. These defensive routines in turns create barriers to communication of valid and exhaustive information. Therefore, the cognitive perspective of the success trap causes unawareness of relevant information and blindness that prevents learning. It is therefore the outcome of an unintended organizational process, while the political perspective of the success trap is the consequence of executives being unwilling to exchange and use relevant information and to discuss relevant issues related to a potentially successful strategic paradigm. It is therefore an intended organizational process.

The success trap phenomenon was very present in the cases of this research. All observed actors, with the exception of the life sciences CEO, were to a certain extent victims of this phenomenon and displayed the complacency (and sometimes arrogance), the cognitively or politically generated blindness to crisis and the inability to change the hitherto successful formula to a changing environment. Many lived in a state of self-created splendid isolation and their behavior can be described as being low in individual vigilance and equally low in social experimentation. Why the life sciences CEO had remained immune to this virus and what his and possibly other executives' strategies could be to prevent falling into this trap could not be conclusively determined in this research, although there were some indications that point to a set of behaviors that can be summarized with the term 'global mindset'. 


\section{THE DOWNSIDE OF TRUST}

Trust is increasingly researched in the M\&A (e. g. Stahl and Sitkin, 2005) and joint venture literature (e.g. Das and Teng, 1998; Currall and Inkpen, 2002; Inkpen and Currall, 2004) where it is usually claimed, as in practice, to be essential for post-merger success: "Mergers are a promise of a better future. If the promise is plausible, it will immediately be honored by the stock market. But employees need much more time to let go of things that worked and try something new. The leaders need to create the perception that the promised future will actually materialize. For this, you need trust; you need a top executive that's credible" Respondent, Chief Communication Officer.

Indeed, the phenomenon of trust played an important role in all the studied cases, albeit not the same. The CEO in the banking merger put a strong accent on trust in a non-trusting environment with the result that vigilance went down too fast and major quality control problems occurred that led to his dismissal. The automotive CEO did not particularly seek trust, whereas the airline and the IT CEOs had periods of trust in their organisations during which singular energies had led to extraordinary achievements (O'Reilly and Pfeffer, 2000), but both lost this trust somewhere en route. In the technology merger trust is not practiced, this CEO clearly stressed financial and technical vigilance over relational and emotional issues (Hunt and Scanlon, 1999; Krass, 1998; Willingham, 1997) and focused on control and standard procedures. The life sciences CEO seems to apply a mixture between trust and distrust, between individual vigilance and social experimentation. In transitional organisations, executives who do not know each other and who usually have not selected each other but find themselves working with each other through circumstances external to them have to collaborate quickly and effectively toward a common goal. For this they need to trust each other, i.e. a certain amount of trust must be given in advance. Especially if one of the key assets of combination is to be tapped, namely the diversity, the rich interconnections between the two merging partners, trust needs to have its place in leadership (Eisenhardt, 2000). Lack of trust and the phenomenon of control-bound thinking is referenced as one reason for poor post-merger performance (Bijlsma-Frankema, 2004; Buono and Bowditch, 1989; Cartwright and Cooper, 1992, 1993a, 1993b; Pritchett and Pound, 1996).

Trust can be conceptualized along the dimension of rationality/irrationality: “...rational actors will place trust (...) if the ratio of the chance of gain to the ratio of the chance of loss is greater than the ratio of the amount of the potential loss to the amount of the potential gain (Coleman, 1990: 99)." Outside this paradigm there seems to be agreement that trust involves some irrationality since it can only have meaning in situations of uncertainty when the trusting person "has incomplete knowledge of the probabilities of the trusted person's behavior (von Lampe and Johansen, 2003)." Trust is therefore not exclusively based on probability calculations but also on such factors as feelings and culturally induced values (e. g. Dunn, 1988; Giddens, 1990; Fukuyama, 1995). Trust is also a mechanism to reduce social complexity. The executive who trusts acts as if only one set of future possibilities existed, that of the purposeful and desired action of others (Hubschmid, 2002). Many scholars claim that trust is a prerequisite for collaboration, especially in situations of transition and/or crisis (Mishra, 1996). Inversely, erosion of trust can lead to a depletion of communication and collaboration (Rüegg-Stürm and Gritsch, 2001) and create a climate of rumours: the communication becomes increasingly strategic and speculations, lies, systematic indiscretions and disinformation increase (Beckert et al, 1998). Information is used as a tool of manipulation and power (Emerson, 1962; Pfeffer, 1992; RüeggStürm and Gritsch, 2001). Constructive conflict resolution is no longer possible because nonconformist behaviour is sanctioned (Hardy et al., 2000; Sinetar, 1988; Zaheer et al., 1998): the 'credit of idiosyncrasy' (Hollander, 1958), which tolerates ambiguity and permits diversity of opinions and the challenging of groupthink (Eisenhardt et al., 1997; Janis, 1972, 1982) and norms is no longer given (Luhmann, 1979). Thus, the literature primarily interested in the conditions for trust and describes mainly the positive effects of trust on collaboration. It is hardly discussed whether trust can also have negative or dangerous effects. Indeed the research displayed many examples of the power trust can have in generating energy and enthusiasm in organisations and aligning them quickly onto a common goal while permitting ambiguity and diversity of thought in the problem-solving process toward that common goal.

But this research also exposed that trust can have severe negative consequences (Fox, 1974; Gambetta, 1988), and that perhaps "...too much trust may be put into the fashionable discourse of trust (Kern, 1996: 9)." These may result from oversimplification and an excessive generalisation of expectations, which can lead to the creation of incongruent expectations and thereby negatively influence the perception and the learning capacity of the actors involved (Gabarro, 1978; Hubschmid, 2002: 367). The literature explicitly concerned with the downside of trust is 
scarce but some explanatory approaches for the negative effects of trust could be found. Concepts such as 'unrealistic' and 'blind' trust (Kern, 1996) are evoked. It is argued that trust, when too tenacious, can become "...inflexibly shaped into a pattern of pervasive trust... (Barnes, 1981)." Trust can also: "...improve the opportunity for wrongdoing (Granovetter, 1985)." The complexity reduction, which permits action in the first place can, if it is excessive, inhibit action and thereby lead to compulsive or obsessive trust (Strasser and Voswinkel). The readiness to explore new things becomes diminished and decisions are made within the range that is permitted by the 'trust agents' (Strasser and Voswinkel, 1997: 234). In such regressed trust systems trust is not given but postulated, which makes such systems vulnerable to human exploitation (Loose and Sydow, 1994). In this research, the leaders' abdication of individual vigilance displayed a number of adverse consequences:

- Incongruent Expectations: Trust can limit the scope of perception through excessive reduction of complexity (Kolbeck and Nicolai, 1996). The observers can be misled by an over-homogenisation and overestimate the coherence of the system (Luhmann, 1989). Trust in relation to time constraints, distance and the high complexity of certain endeavours - all phenomena of transitional and post-merger situations - can lead to wrong expectations and to a disregard for the context in which trust is given: "One form of irrationality in trust relationships (...) is to forget the background against which elements of trust exist (Sheppard and Sherman, 1998)." Excessive trust can also obtain a 'character of exclusivity' (Hubschmid, 2002: 369; Loose and Sydow, 1994) motivated by an overreaching strive for harmony, which leads to isolation of the trusting group vis-à-vis other stakeholders and to a strengthening of mutual points of view within the group. This again can provoke a feeling of invulnerability and an exaggerated confidence in the group's capacity to act (Hubschmid, 2002; Mishra, 1996; Webb, 1996: 290).

- $\quad$ Blind Trust: Giddens argues that: “....all trust is in a certain sense blind trust. (Giddens, 1990: 33)” Others see blind trust as being at the border of the phenomenon of trust (Shaw, 1997: 15) or as an extreme case of the disposition of trust (Mayer et al., 1995: 715). Others again argue that blind trust is not part of the concept of trust since it does not - as the adjective "blind indicates - reflect any of the parameters such as the perception of uncertainty, expectations or vulnerability nor the trustworthiness of the trusted person (Powell, 1996; Weibler, 1997). Influential factors that may favour blind trust are reported to be a high interest in common action by the CEO, 'good faith' turning into 'tenacious good faith (Hubschmid, 2002: 372; Mayer et al., 1995)' under pressure; information exchange and collaboration hampered by time pressure, distance and complexity of the task (Sheppard and Sherman, 1998: 425); fear of worsening the situation by questioning things - by challenging the trust (Boos and Heitger, 1996: 174), organisational design and collective mistrust vis-à-vis a common opponent.

- $\quad$ Learning Dysfunction: The consequences of trust induced incongruent expectations and of blind trust upon individual and organisational learning capacity are found to be important. In transitional systems premature trust is given, which permits a collective perception capable of dealing with vulnerability, insecurity, risk and expectations. This can lead to the 'starke Weltanschauung' (German, Engl. translation: 'strong world view': in societies where trust is a condition for membership a common understanding is shaped by interaction and sharing of knowledge between members and groups, whereby the knowledge becomes universal. Gergen (1995) dubs a similar viewpoint as 'local ontology' that Sabel describes in societies where to trust each other is a prerequisite for membership (1993). Such a situation in which members have no possibility to verify the claims of truth and legitimacy made by the established authority may lead to over-identification and to dogmatism, rather than to learning and to distraction rather than sensitivity. Kramer et al speak of the 'dark sides of identity-based trust' and note insufficient observation of warning signals, an overestimation of mutual favours and a deceleration of reaction time (1996). This leads to a slowdown of learning. Hubschmid notes that the learning capability depends as much on the capability of trusting other points of view as on the capability of challenging these very points of view (2002: 373). Also, if individuals trust that others will take action they may refrain from personal intervention: "Thus, an unintended (and ironic) consequence of high levels of presumptive trust in others may be that individuals underestimate the need for personal action. (Kramer et al., 1996: 379)" Husted speaks of the 'high trust syndrome' and notes that the relationship between organisational members is diffuse and problems are perceived to be a natural part of any relationship (1989: 28). 
- $\quad$ Risk Of Indifference: Some merger teams experienced a 'drift into indifference' and the merger was being used as a motive to roll off problems or not to assume responsibilities based on an attitude of noninterference (Hubschmid, 2002: 374). Luhmann sees the 'upsurge into indifference' as a positive effect of trust and argues that trust can occult certain scenarios, certain dangers, which cannot be eliminated but which should not irritate the action (1989). Trust therefore reflects contingency (Giddens, 1990): realities become simpler, risks become more calculable and a psychological relief and a social 'canalisation' is created. Giddens (1990) calls this concept a 'cocoon', which protects the actors from frustration and uncertainty, Gambetta (1988) calls it the 'means to cope with the freedom of others'. In this sense, the dimension of indifference can indeed be seen as containing both positive and negative effects. It is, as often, a question of measure and it is the exaggerated strive for harmony and the uncritical mutual trust that bear the risk of mediocrity and even failure (Krystek and Zumbrock, 1993).

- $\quad$ Trust As A Prison: Hubschmid has analysed that trust can lead to a 'self-imposed pressure on to the trusted persons', which has had an imprisoning effect (2002: 375). In times of extreme crisis, CEOs do no longer feel free to make the decisions they deem necessary because this would have led to more uncertainty in an already unbearably uncertain situation. They feel forced to act according to expectations, i.e. contrary to their preoccupations (2002: 292). Luhmann calls this phenomenon 'trust as a handcuff': the personal formation of expectations is abandoned in favour of an internalisation of the expectations of the opponent ('Vertrauen als Fessel', Luhmann, 1989: 71).

- $\quad$ Abuse: Abuse is the intrinsic risk that is accepted when giving trust. The literature sees abuse as the central danger of trust giving (Zaheer et al., 1998). Again, the measure of individual vigilance is decisive: in a context of 'compulsive trust', in which control mechanisms have been forsaken, opportunities for malevolence and manipulation increase (Kraysteck and Zumbrock, 1993; Shaw, 1997; Sydow, 2000: 57). People rely on the assumption that their modest commitment to the cause will not be discovered (Beckert et al, 1998) or that their violation will by drowned within the ensemble of the organisation. When abuse becomes apparent it can lead to: "...chronic debilitating distrust and, ultimately, in organizational failure (Mishra, 1996)."

A culture of excessive trust, i.e. of insufficient individual vigilance and high social experimentation can lead to incongruent expectations, to a limitation of the horizons of action and to a feeling of invulnerability. This in turns diminishes the learning ability and slows down the reaction time. It can therefore been said that the phenomenon of distrust also has its place in organizations. Vigilance and distrust are not necessarily results of irrational fears but can be the results of solid experiences and knowledge (Lewicki et al, 1998). Trust and distrust seem to be interdependent opposites, i.e. distrust may be the very prerequisite for trust to function satisfactorily. For trust to function, the general social risk capability and the risk of disappointment need to be monitored (Luhmann 1989).

\section{GLOBAL MINDSET}

The concept of global mindset (Hong et al., 2000; Manolova et al., 2002; Nummela et al, 2004; Stanek, 2000) was observed to influence managerial action in the merger cases. This is not surprising since one of the success factors of post-merger management is acculturation. Many respondents regretfully stated that they "...did not have enough global managers". While there is no research that directly examines global mindset and post-merger organizations, there is a growing body of knowledge on the executive's global mindset and the capacity to internationalize (Gregersen et al., 1998; Harveston et al., 2000; Knight, 2001; Nummela et al, 2004). Since cross-national mergers are a way of internationalizing it is likely that findings from this research will at least partly apply. The concept of global mindset includes attitudinal and behavioral aspects. In organization theory and cognitive psychology, mindset refers to the way humans make sense of the world. An executive with a global mindset is said to:

- $\quad$ represent an executive's positive attitude towards international affairs (van Bulck, 1979)

- $\quad$ openness to and awareness of cultural diversity and the ability to cope with it (Fletcher, 2000; Gupta and Govindarajan, 2002; Kedia and Mukherji, 1999)

- $\quad$ respect how things are different and be capable of imagining why things are different (Taylor (1991) citing Percy Barnevik, ex-CEO and conceptor of the Swedish-Swiss ABB merger) 
- $\quad$ have the capacity to be 'incisive' as well as generous and patient (Bartlett and Ghosal, 1998)

- have interest, inquisitiveness and curiosity in foreign cultures and a generally cosmopolitan orientation; an attitude that considers uncertainty and unfamiliarity as a 'fuel' for discovery (Black et al., 1998)

- have an understanding of his or her own roots, be flexible in cultural issues and adaptable to new things (Brake et al., 1995)

- have a drive to communicate, be rather extroverted, have a broad-based sociability (Black and Gregersen, 1999)

- $\quad$ have a collaborative negotiating style (Black and Gregersen, 1999; Stanek, 2000).

A global mindset is reflected in the active and visionary behavior of executives to be prepared to take risks in building cross-border relationships. However, global mindset is not sufficient and executives must also have the knowledge and capability to sustain it. Global mindset is a dynamic concept that interacts with its surrounding field and is permanently revised as learning takes place and experience accumulates (Fletcher, 2000). In cross-border mergers, moreover, at least three levels of culture differences have to be managed, the individual level, the organizational level and the national level (Gertsen et al., 1998; Heidrich, 2002; Morosini, 1998; Very et al., 1998). There is a large body of literature on cultural differences as a major cause of merger integration problems (Slowinski et al., 2002). This research is mostly based on organizational (e. g. Buono et al., 1985; Cartwright and Cooper, 1993a, 1993b; Chatterjee et al. 1992; Sales and Mirvis, 1984) and/or national/regional cultural differences (e. g. Calori et al., 1994; Gertsen et al., 1998; Morosini et al., 1998; Weber and Menipaz, 2003). It was interesting that in this research some lesser researched cultural differences were more pronounced, e. g. differences in entrepreneurial attitude and in internet literacy. In the automotive merger, while the differences that were evoked by executives were 'German' vs. 'US', but when enquired more deeply the incompatibilities were more between the entrepreneurial, market-oriented spirits and the hierarchical, product-oriented characters. And although one would typically expect the former in the US and the latter in Germany, there were in fact many occurrences of resistance within Germany between entrepreneurial and hierarchical managers. Similarly, substantial cultural incompatibilities were observed in the technology merger where executives from different industries had very different leadership and communication styles. Some did not use the internet at all, while others used all and often exclusively modern media, such as websites, databases, blogs, SMS and email. As a consequence of this, some executives (those that did not master or had not internalized the new communication technologies) were simply not sufficiently informed or not informed in time. A global mindset can understand and anticipate such cultural differences and turn them from a major difficulty in mergers to a source of value (Fendt, 2006; Krishnan et al., 1997; Morosini et al, 1998).

Research on the relationship between global mindset and performance is scarce but there seems to be some evidence that companies led by executives with global mindset internationalize faster (Harveston et al., 2000; Knight, 2001; Madsen and Servais, 1997), although not all researchers have found evidence for this (Nummela et al., 2004). The benefits of a global mindset are stark. They lie in the respect and curiosity to discover how the other culture works and in a willingness to learn the best of it and to assimilate it with ones own experiences. Practically this means that such executives are ready to internalize structural, processual and cultural elements of the foreign partner if these are deemed better and combine them with the strengths of their own organization. In line with the above, 'foreign' can refer to any cultural unfamiliarity (i. e. foreign communication style, or foreign attitude toward risk-taking) and is not limited to the usual national or organizational incompatibilities. This leads to an increase in the use of common processes, in an improvement of these processes - irrespective of any power rationale, i.e. whether these processes stem from the stronger or weaker merger partner (Fendt, 2005) - in reduced costs with duplication efforts and, above all, in a reduction of the confusion and resistance factors (Conn and Yip, 1997). Still, what seemed logical in view of the synergies sought was in reality difficult because of the "not-invented-here-syndrome (Beer, 1980)". Executives in environments where the global mindset was missing spend an inordinate amount of their time reconciling conflicting information based on multiple practices and systems in use. For example, the technology CEO had, since his early career days as a warehouse clerk, developed a global outlook. His career had taken him around the world to the extent that "...place and time had become mere coordinates" to him as he put it and the companies he restructured were internationalized both organically and by acquisition. However, there were limits to his capacities in that he did not attempt to master the languages of the countries he was involved in, except some business English. Nor was he much interested in getting to know the local cultures beyond bringing home some Asian bauble from his business trips. But mastery of foreign languages and interest and experience in foreign countries are listed as components of global mind- 
set in Dichtl et al. (1990), Holzmüller and Kasper (1990) and Nummela et al (2004). Both he and the automotive CEO had conqueror's mindsets, i.e. they sought to take over the foreign culture and internalize it by annihilation. Such executives tended to attract, select and develop similar executives within their organizations. Inversely, executives with a global mindset shaped a culture within their organizations that attracted multicultural individuals.

Research locates rationales for the absence of global mindset in executives - and the lack of executives with global mindset and the capability to sustain it -in the fact that young executives are being sent abroad primarily for specific assignments necessitating technical competencies or fire fighting abilities, to solve an immediate business problem, crisis or both, such as a plant dissolution or legal issues - or mergers. This has consequences on the selection of the candidate - he or she would need technical or legal skills and, above all, simply be available 'right then'. Therefore, since such assignments were usually ignited by an immediate problem, language and cultural training were usually skipped and no time was allocated to adjusting to the settings (Whitman, 1999). Often such quick fix assignment result in failure and the expatriates repatriate early and/or leave the company.

A more systematic and long-term approach to the development of global competencies is required as is beginning to be implemented in most large companies with regard to selection and training. Still, none of the cases, even those with such long-term planning in place, were entirely prepared for the merger situation, when a multitude of executives were suddenly needed to be transferred from one part of the globe to another. Companies are well advises to practice regular and abundant cross-border exchange of executives in multi-national organizations, well before any merger project is in sight. Since executives are often not keen on letting their best talents go it may be necessary to formalize this goal and link it to incentives.

\section{CONCLUSIONS AND FURTHER RESEARCH}

Abstraction of the data suggests that the four identified concepts of managerialism vs. leadership, success trap, excess of trust and global mindset can all be situated in a discussion around the management of the dichotomy, or the apparent dichotomy of individualized vigilance and social experimentation (Figure 2 on next page). While the data evidenced that the executives who displayed both high individual vigilance and high social experimentation were particularly successful in managing the multiple cultural realities, logical inconsistencies and general complexity of their post-merger environments, it is not conclusive in how this process works exactly, given that these two strategies are to a certain extent dichotomic. Answers may be found in the literature on the management of strategic dilemmi. Strategic dilemmi, such as the one identified by March (1991) dealing with the simultaneous need for firms to improve exploitation of existing business while exploring new venues, are the management of difficult choices in the context of scarce resources. What is common to all dilemmas is that we witness two opposing poles that are influencing a person or an organization's behavior. More often, it is insufficient to make an either-or decision, but, as evidenced in this paper in the case of individual vigilance and social experimentation, two apparently irreconcilable behaviors need both be chosen. For some researchers the resulting behavior is typically somewhere on the dimensional line between the two extremes: neither where it would be if one pole were completely dominant, nor where it would be in the reverse case of total domination by the other.

Much strategic dilemma research focuses on how to best "synthesize" or "balance" the opposing forces. Naturally one tends to search for "balance" but then again this connotes "a state of equilibrium or equipoise; equality in amount, weight, value or importance, as between two things or the parts of a thing" or even "equilibrium or stability" as in "keeping a balance on a tightrope" (Webster, 1978: 105). For example, in the abundant body of knowledge on exploitation vs. exploration the search for "balance" prevails, albeit some authors describe sequential rather than simultaneous achievement of balance between exploration and exploitation, but as a rule address life-cycle stages of organizational life (for a review of both the "simultaneous" and "sequential" approaches see Chen, 2005). March himself advocates this in his seminal paper (1991: 71) although he later evolves towards the concept of an "optimal mix". Many others agree to a greater or lesser extent, for example Bradach (1997), Brown and Eisenhardt (1997) and Cardinal et al (2004). Christensen and Foss (1997), Tushman and O'Reilly (1996), Tushman and Smith (2002) and Warglien (2002) evoke balance and equilibrium, but also focus on "synergistic dynamics." Sachs et al (2006) purport the analogies of two activities that are critically dependent on maintaining a balance: walking a tight rope and riding a bike. In both, it is argued, the "balance" is dynamic: (1) weight is shifted by moving sideways and forward and back 
while the body's centre of gravity also moves up and down, and (2) context-driven: winds, curves, road works, slippery roads, etc. Aiming for static balance is therefore ill suited to a fast-paced world (Brown and Eisenhardt, 1997). At some point, the time it takes to arrive at an optimal design is slower than the rate at which competitive conditions change (Schön, 1971). Optimum designs slow firms down as they become more global, more dispersed, more integrated into multiple local cultures that change at varying rates, more hooked into leading-edge technologies, more dependent on rapidly changing consumer tastes (Halal and Taylor, 1999; Sachs et al, 2006; Sanchez and Mahoney, 1996), more likely to engage in mergers and acquisitions for a variety of rationales (Fendt, 2005), or as products change from "things that clank" to "things that change at the whim of a software programmer" (Jennings and Haughton, 2000; Prusak, 1996). McKenzie and van Winkelen (2004) advocate oscillation dynamics because the Knowledge Era calls for changeable organizations, not just knowledgeable ones. This is just a brief outline of the type of questions that shall be addressed in a next paper on the relationship between the management of individual vigilance and social experimentation in an attempt to add a dynamic component to the above proposed framework.

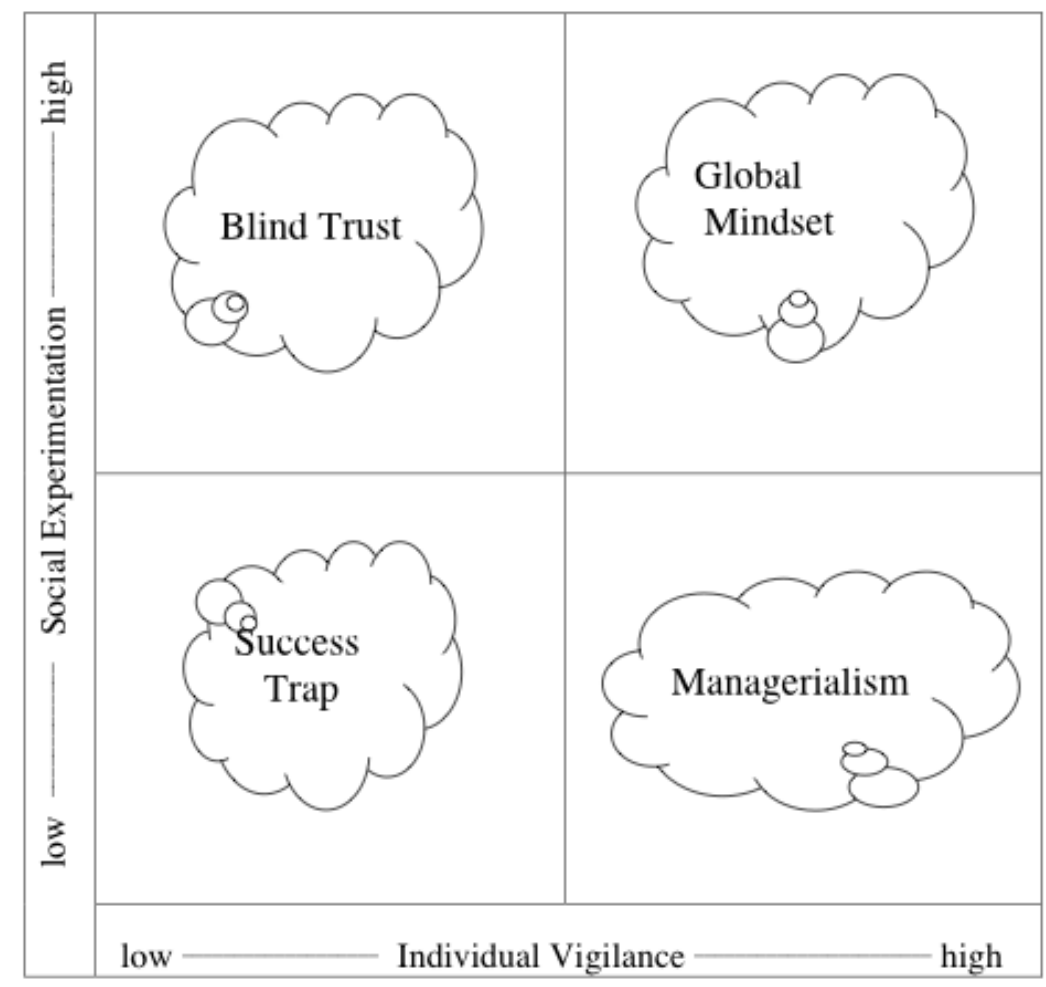

Figure 2: The Social Experimentation/Individual Vigilance Framework

\section{REFERENCES}

1. Alvesson, M. and H. Willmott, Making Sense of Management: A Critical Introduction. Sage, London, 1996.

2. Argyris, C., Good Communication that Blocks Learning. Harvard Business Review Jul-Aug 77-91, 1994.

3. Argyris, C. and D. A. Schön, Organization Learning: A Theory of Action Perspective. Addison-Wesley, Reading, MA., 1978.

4. Ashkenas, R. N. and S. C. Francis, Integration Managers: Special Leaders for Special Times. Harvard Business Review 78 (Nov/Dec) 108-117, 2000.

5. Askvik, S. and B. Espedal, The Success Trap in Organizational Learning: Cognitive and Political Explanation. Proc. 3rd European Conf. Organ. Knowledge, Learning and Capabilities. Athens, 2002.

6. Barnes, L., Managing the Paradox of Organizational Trust. Harvard Business Review 59 107-115, 1981. 
7. Bartlett, C.A. and S. Ghoshal, Managing Across Borders: The Transnational Solution. 2nd ed. Harvard Business School Press, Boston, 1998.

8. Beckert, J., A. Metzner, and H. Roehl, Vertrauenserosion als organisatorische Gefahr und wie ihr zu begegnen ist. Organisationsentwicklung. 4 56-63, 1998.

9. Beer, M., Organization Change and Development. Goodyear, Santa Monica, 1980.

10. Berle, A. A. and G. C. Means, The Modern Corporation and Private Property. Macmillan, New York, 1933.

11. Bijlsma-Frankema, K., Dilemmas of Managerial Control in Post-acquisition Processes. Journal of Management Psychology 19 (3) 252-268, 2004

12. Black, J. S. and H. B. Gregersen, The Right Way to Manage Expats. Harvard Business Review, 77 52-63, 1999

13. Black, J. S., H. B. Gregersen, and A. J. Morrison, Developing Leaders for the Global Frontier. Sloan Management Review, 40 21-32, 1998

14. Boje, D. M., Managerialist Storytelling. http://cbae.nmsu.edu/ dboje/managerialist.html 2002 (29.9.2004).

15. Boos, F. and B. Heitger, Kunst oder Technik? Der Projektmanager als sozialer Architekt. Balck, ed. Networking und Projektorientierung - Gestaltung des Wandels in Unternehmen und Märkten. Springer, Berlin, 1996.

16. Bradach, J. L., Using the Plural Form in the Management of Restaurant Chains. Administrative Science Quarterly 42 276-303, 1997.

17. Brake, T., D. M. Walker, and T. Walker, Doing Business Internationally: The Guide to Cross-Cultural Success. McGraw-Hill, New York, 1995.

18. Brown, S. L. and K. M. Eisenhardt, The Art of Continuous Change: Linking Complexity Theory and Timepaced Evolution in Relentlessly Shifting Organizations. Administrative Science Quarterly, 42 1-34, 1997.

19. Buono, A. F., J. L. Bowditch, and J. W. Lewis, When Cultures Collide: the Anatomy of a Merger. Human Relations 38 (5) 477-500, 1985.

20. Buono, A. F. and J. L. Bowditch, The Human Side of Mergers and Acquisitions: Managing Collision between People, Cultures and Organizations. Jossey-Bass, San Francisco, 1989.

21. Calori, R., M. H. Lubatkin, and P. Very, Control Mechanisms in Cross-border Acquisitions: an International Comparison. Organisation Studies 15 (3) 361-379, 1994.

22. Cardinal, L. B., S. B. Sitkin, and C.P. Long, Balancing and Rebalancing in the Creation and Evolution of Organizational Control. Organization Science 15 411-431, 2004.

23. Cartwright, S. and C. L. Cooper, Mergers and Acquisitions: The Human Factor. Butterworth, Oxford, 1992.

24. Cartwright, S. and C. L. Cooper, The Psychological Impact of Merger and Acquisition on the Individual: a Study of Building Society Managers. Human Relations 46 327-347, 1993 a.

25. Cartwright, S. and C. L. Cooper, Of Mergers, Marriage and Divorce: the Issue of Staff Retention. Journal of Managerial Psychology 8 (6) 7-10, 1993 b.

26. Chandler, A., The Visible Hand. Harvard University Press, Cambridge, 1977.

27. Charman, A., AT Kearney Study. M. H. Haebeck, F. Kroger, and M. R. Trum, eds. After the Mergers: Seven Rules for Successful Post-Merger Integration. Prentice Hall, New York, 1998.

28. Chatterjee, S. M., H. Lubatkin, D. M. Schweiger, and Y. Weber, Cultural Differences and Shareholder Value in Related Mergers: Linking Equity and Human Capital. Strategic Management Journal 13 319-334, 1992.

29. Chen, E. L., Rival Interpretations of Balancing Exploration and Exploitation; Simultaneous or Sequential. Proceedings Academy of Management Annual Meeting, Honolulu, 2005.

30. Chesbrough, H. W. and D. J. Teece, When is Virtual Virtuous? Organizing for Innovation. Harvard Business Review 74 (1) 65-72, 1996.

31. Child, J., D. Faulkner, and R. Pitkethly, The Management of International Acquisitions. Oxford University Press, 2001.

32. Christensen, J. F. and N. J. Foss, Dynamic Corporate Coherence and Competence-Based Competition: Theoretical Foundations and Practical Implications. A. Heene, R. Sanchez, eds. Competence-Based Strategic Management. Wiley and Sons, Chichester and New York, 1997.

33. Chussil, M., With all this Intelligence, Why Don't We Have Better Strategies? Journal of Business Strategy 26 (1) 26-33, 2005.

34. Coleman, J. W., Foundations of Social Theory. Belknap Press, Cambridge, 1990.

35. Colvin, G., The Great CEO Pay Heist. Fortune. (June 25 ${ }^{\text {th }}$ ) 64-66, 2001. 
36. Conn, H. P. and G. S. Yip, Global Transfer of Critical Capabilities. Business Horizons 40 22-31, 1997.

37. Courtney, H., Decision-Driven Scenarios for Assessing Four Levels of Uncertainty. Strategy \& Leadership 31 (1) 14-22, 2003.

38. Croyle, R. and P. Kager, Giving Mergers a Head Start. Harvard Business Review Oct. 2002.

39. Csikszentmihalyi, M., Flow: The Psychology of Optimal Experience. HarperCollins, New York, 1990.

40. Currall, S. C. and A. C. Inkpen, A Multilevel Approach to Trust in Joint Ventures. Journal of Internat. Bus. Stud. 33 479-495, 2002.

41. Currall, S. C. and A. C. Inkpen, Strategic Alliances and the Evolution of Trust Across Levels. M. West, D. Tjosvold, K. Smith, eds. International Handbook of Organizational Teamwork and Cooperative Working. John Wiley \& Sons, New York, 533-549, 2003.

42. Cyert, R. M. and J. G. March, A Behavioral Theory of the Firm. Prentice Hall, Englewood Cliffs, 1963.

43. Das, T. K. and B. S. Teng, Trust, control and risk in strategic alliances: an integrated framework. Organization Studies 22 251-283, 2001.

44. Davis, F., A Yearning for Yesterday: A Sociology of Nostalgia. MacMillan, London, 1979.

45. Dichtl, E., H.-G. Koeglmayr, and S. Mueller, International Orientation as a Precondition for Export Success. Journal of International Business Studies 21 (1) 23-40, 1990.

46. Diener, E. and R. J. Larsen, The Experience of Emotional Well-being. M. Lewis, J. M. Haviland eds. Handbook of Emotions. 325-227. Guilford, New York, 1993.

47. Dunn, J., Trust and Political Agency. D. Gambetta ed. Making and Breaking Corporate Relations. Blackwell, New York, 73-93, 1988.

48. Eisenhardt, K. M., Paradox, Spirals, Ambivalence: The New Language of Change and Pluralism. Academy of Management Review 25 (4) 703-705, 2000.

49. Eisenhardt, K. M., J. L. Kahwajy, and L. J. Bourgeois III, Conflict and Strategic Choice: How Top Management Teams Disagree. California Management Review 39 (2) 42-62, 1997.

50. $\quad$ Emerson, R. M., Power-dependence Relations. American Sociological Review 27 31-41, 1962.

51. Enteman, W., Managerialism: the Emergence of a New Ideology. University of Wisconsin Press, 1993.

52. Farmer, R., After the Courtship: Managing Merger Transitions. Banking Management. 72 (3) 34-36, 1996.

53. Fendt, J., The CEO in Post-Merger Situations: An Emerging Theory on the Management of Multiple Realities. Eburon, Delft, 2005.

54. Fendt, J., The CEO in the Post-merger Maze: Managing Dilemmi, Paradox and Polychotomies. Leiden University Working Paper, 2006.

55. Fiol, C. M., Consensus, Diversity and Learning in Organizations. Organization Science 5 403-420, 1994.

56. Fletcher, S., A Role for Imagery in Mentoring. Career Developement International 5 (4-5) 235-243, 2000.

57. Fligstein, N., The Transformation of Corporate Control. Harvard University Press, Cambridge, 1990.

58. Fortgang, R. S., D. A. Lax, and J. K. Sebenius, Negotiating the Spirit of the Deal. Harvard Business Review Feb. 2003.

59. Fox, A., Beyond Contract: Work, Power and Trust Relations. Faber, London, 1974.

60. Fukuyama, F., Trust: The Social Virtues and the Creation of Prosperity. Free Press, New York, 1995.

61. Fulmer, W. E., Shaping the Adaptive Organization - Landscapes, Learning and Leadership in Volatile Times. Amacom, New York, 2000.

62. Gabarro, J. J., The Development of Trust, Influence and Expectations. A. Athos, J. J. Gabarro eds. Interpersonal Behavior: Communication and Understanding in Relationships. Prentice Hall, Englewood Cliffs, 290303, 1978.

63. Galpin, T. and M. Herndon eds., The Complete Guide to Mergers and Acquisitions - Process Tools to Support M\&A Integration at Every Level. Watson Wyatt Worldwide, 2001.

64. Gambetta, D., Can we Trust Trust? D. Gambetta ed. Trust: Making and Breaking Cooperative Relations. Blackwell, New York, 213-237, 1988.

65. Gephart, R. P., Status Degradation and Organizational Succession: An Ethnomethodological Approach. Administrative Science Quarterly 23 (4) 553-581, 1978.

66. Gephart, R. P., Sensemaking, Communicative Distortion and the Logic of Public Inquiry Legitimation. Industrial Crisis Quart. 6 (2) 115-135, 1992.

67. Gergen, K. J., Relational Theory and the Discourses of Power. D. M. Hosking, H. P. Dachler, and K. J. Gergen eds. Management and Organization: Relational Alternatives to Individualism. Aldershot, Avebury, 1995. 
68. Gertsen, M. C., A. M. Søderberg, and J. E. Torp eds., Cultural Dimensions of International Mergers and Acquisitions. De Gruyter, Berlin, 1998.

69. Giddens, A., The Consequences of Modernity. Polity, Cambridge, 1990.

70. Gladwell, M., The Tipping Point: How Little Things Can Make a Big Difference. Little Brown \& Co., New York, 2002.

71. Goleman, D., Emotional Intelligence: Why It Can Matter More Than IQ. Bantam Export Edition, New York, 1995.

72. Goleman, D., What makes a leader? Harvard Bus. Rev. 76 (6) 93-102, 1998.

73. Goleman, D., Emotional Intelligence in Mergers and Acquisitions: The Hidden Force. Focus Online. http://www.ceoforum.com.au/200304_leadership.cfm 1999 (27.9.2004)

74. Goulding, C., Grounded Theory - A Practical Guide for Management, Business and Market Researchers. Sage, London, 2002.

75. Granovetter, M., Economic Action and Social Structure: The Problem of Embeddedness. Amer. Journal of Sociol. 91 481-510, 1985.

76. Green, H., Managing M\&A Integrations. CEO Forum. http://www.ceoforum.com.au/200304_leadership.cfm 2004 (27.9.2004)

77. Gregersen, H. B., A. J. Morrison, and J. S. Black, Developing Leaders for the Global Frontier. Sloan Management Rev. 40 (1) 21-32, 1998.

78. Grubb, T. M. and R. Lamb, Capitalize on Merger Chaos: Six Ways to Profit From Your Competitors' Consolidation and Your Own. Free Press, New York, 2001.

79. Gupta, A. K. and V. Govindarajan, Cultivating a Global Mindset. Academy of Management Executive. 16 (1) 116-126, 2002.

80. Halal, W. E. and K.B. Taylor, 21st Century Economics: Perspectives of Socioeconomics for a Changing World. Macmillan, New York, 1999.

81. Haleblian, J. and S. Finkelstein, The Influence of Organizational Acquisition Experience on Acquisition Performance: A Behavioral Perspective. Administrative Science Quarterly 44 (1) 29-56, 1999.

82. Hambrick, D. C., I. C. MacMillan, and D. C. Day, Strategic Attributes and Performance of Businesses in the Four Cells of the BCG Matrix. Academy of Management Journal 25 (3) 510-531, 1982.

83. Hambrick, D. C. and P. A. Mason, Upper Echelon: The Organization as a Reflection of its Top Managers. Academy of Management Review 9 193-206, 1984.

84. Handy, C., The Hungry Spirit. Broadway Books, New York, 1998.

85. Hardy, C., N. Phillips, and T. B. Lawrence, Distinguishing Trust and Power in Interorganizational Relations: Forms and Facades of Trust. C. Lane and R. Bachmann eds. Trust Within and Between Organizations - Conceptual Issues and Empirical Applications. Oxford University Press, New York, 64-87, 2000.

86. Harveston, P. D., B. L. Kedia, and P. S. Davis, Internationalization of Born Global and Gradual Globalizing Firms: The Impact of the Manager. Advances Competitiveness Research 8 (1) 92-99, 2000.

87. Heames, J. T. and R. W. Service, Dichotomies in Teaching, Application and Ethics. Journal of Education for Business 79 (2) 118-122, 2003

88. Hedberg, B., How Organizations Learn and Unlearn. P. C. Nystrom, W. H. Starbuck eds. Handbook of Organizational Design. Volume 1: Adapting Organizations to their Environments. Oxford University Press, New York, 1-27, 1981.

89. Heidrich, B., Business as Usual - The Role of National Cultural Background in Corporate Life. European Integration Studies 1 (2) 25-36, 2002.

90. Hickman, C. R., Mind of a Manager, Soul of a Leader. Wiley \& Sons, New York, 1990.

91. Hollander, E. P., Conformity, Status and Idiosyncrasy Credit. Psychological Review 65 117-127, 1958.

92. Holzmüller, H. H. and H. Kasper, The Decision Maker and Export Activity: A Crossnational Comparison of the Foreign Orientation of Austrian Managers. Management International Review 30 (3) 217-230, 1990.

93. Hong, Y., M. W. Morris, C. Chiu, and V. Benet-Martinez, Multicultural Minds - A Dynamic Constructivist Approach to Culture and Cognition. American Psychologist 55 (7) 709-720, 2000.

94. Hooijberg, R. and R. E. Quinn, Behavioral Complexity and the Development of Effective Managers. R. L. Phillips and J. G. Hunt eds. Strategic Leadership: A Multi-Organizational-Level Perspective. 161-176. Quorum, London, 1992. 
95. House, R. J. and R. N. Aditya, The Social Scientific Study of Leadership: Quo Vadis? Journal of Management 23 409-473, 1997.

96. Hubbard, N., Acquisition Strategy and Implementation. MacMillan, London, 1999.

97. Huber, G. P., Organizational Learning: The Contributing Processes and the Literatures. M. D. Cohen and L. S. Sproull eds . Organizational Learning. Sage, London, 124-162, 1996.

98. Hubschmid, C. C., Vertrauen im komplexen organisationalen Arrangement - der Fall Expo. Diss. No. 2626, University of St. Gallen, Switzerland, 2002.

99. Hunt, C. W. and S. A. Scanlon eds., Navigating Your Career. Wiley, New York, 1999.

100. Hussey, D., Merger and Acquisition: More Often Wrong Than Right? Strategic Direction. 17 (3), 2002.

101. Husted, B., Trust in Business Relations: Directions for Empirical Research. Business and Professional Ethics J. 8 (2) 23-40, 1989.

102. IHM Research Update, Institute of HeartMath, Boulder Creek, CA. 1 (1) 3, 1993.

103. Inkpen, A. C. and S. C. Currall, Coevolution of Trust, Control and Learning in Joint Ventures. Organization Science 15 (5) 586-599, 2004.

104. Jackson, S. E. and R. S. Schuler, Managing Human Resources Through Strategic Partnerships: Chapter 16, 2002. http://www.swcollege.com/management/jackson/jackson.html (12.9.2004)

105. Janis, I., Victims of Groupthink. Houghton-Mifflin, Boston, 1972.

106. Janis, I., Groupthink: Psychological Studies of Policy Decisions and Fiascos. Houghton Mifflin, Boston, 1982.

107. Jennings, J. and L. Haughton, It's not the Big that Eat the Small... It's the Fast that Eat the Slow. HarperCollins, New York, 2000.

108. Kedia, B. L. and A. Mukherji, Global Managers: Developing a Mindset for Global Competitiveness. Journal of World Business 34 (3) 230-251, 1999.

109. Keite, L., Fusionen: einen Schritt vor, zwei zurück. Absatzwirtschaft 9 58-64, 2001.

110. Kern, H., Vertrauensverlust und blindes Vertrauen: Integrationsprobleme im ökonomischen Handeln. SOFI Mitteilung 24 7-14, 1996.

111. Knight, G. A., Entrepreneurship and Strategy in the International SME. Journal of International Management 7 (3) 155-171, 2001.

112. Kolbeck C. and A. Nicolai, Von der Organisation der Kultur zur Kultur der Organisation - Kritische Perspektiven eines neueren systemtheoretischen Modells. Theorie der Unternehmung 5, 1996.

113. Kotter, J. P., What Leaders Really Do. Harvard Bus. Rev. May/June, 1990.

114. Kouzes, J. M. and B. Z. Posner, The Leadership Challenge: How To Keep Getting Extraordinary Things Done in Organizations. 2nd Ed. Jossey-Bass, San Francisco, 1987.

115. Kramer, R. M., M. B. Brewer, and B. A. Hanna, Collective Trust and Collective Action - The Decision to Trust as a Social Action. R. M. Kramer, T. R. Tyler eds. Trust in Organizations - Frontiers of Theory and Research. Sage, Thousand Oaks, 357-389, 1996.

116. $\quad$ Krass, P. ed., The Book of Leadership Wisdom. Wiley, New York, 1998.

117. Krishnan, H. A., A. Miller, and W. Q. Judge, Diversification and Top Management Team Complementarity: Is Performance Improved by Merging Similar or Dissimilar Teams? Strategic Management Journal 18 (5) 361-374, 1997.

118. Krug, J. A., Why Do They Keep Leaving? Harvard Business Review Feb 2003.

119. Krysteck, U. and S. Zumbrock, Planung und Vertrauen - Die Bedeutung von Vertrauen und Misstrauen für die Qualität von Planungs- und Kontrollsystemen. Stuttgart, 1993.

120. Levitt, B. and J. G. March, Organizational Learning. Annual Review of Sociology 14 319-340, 1988.

121. Lewicki, R., D. McAllister, and R. Bies, Trust and Distrust: New Relationships and Realities. Academy of Management Review 23 (3) 438-458, 1998.

122. Lipnack, J. and J. Stamps, Virtuelle Teams - Projekte ohne Grenzen: Teambildung, virtuelle Orte, Intelligentes Arbeiten, Vertrauen in Teams. Wien, 1998.

123. Loose, A. and J. Sydow, Vertrauen und Ökonomie in Netzwerkbeziehungen - Strukturationstheoretische Betrachtungen. J. Sydow, A. Windeler eds. Management interorganisationaler Beziehungen - Vertrauen, Kontrolle und Informationstechnik. Westdeutscher Verlag, Opladen, 160-193, 1994.

124. Luhmann, N., Trust and Power. Wiley and Sons, Chichester, 1979.

125. Luhmann, N., Vertrauen - Ein Mechanismus zur Reduktion sozialer Komplexität. Stuttgart, 1989. 
126. Madsen, T. K. and P. Servais, The Internationalization of Born Globals: An Evolutionary Process? International Business Review 6 (6) 561-583, 1997.

127. Manolova, T. S., C. G. Brush, L. F. Edelman, and P. G. Greene, Internationalization of Small Firms: Personal Factors Revisited. Internat. Small Bus. J. 20 (1) 9-31, 2001.

128. March, J. G., Exploration and Exploitation in Organization Learning. Organization Science 2 71-87, 1001.

129. March, J. G., Three Lectures on Efficiency and Adaptiveness in Organizations. Research Report, Swedish School of Economics and Business Administration, Helsinfors, 1994.

130. Marcuse, H., One Dimensional Man. Beacon Press, Boston, 1964.

131. Martin, J. and K. Knopoff, The Gendered Implications of Apparently Gender-Neutral Theory: Re-Reading Weber. E. Freeman, and A. Larson eds. Business Ethics and Women's Studies Volume 3, 1995.

132. Mayer, R., J. Davis, and D. Schoorman, An Integrative Model of Organizational Trust. Academy of Management Review 20 (3) 709-734, 1995.

133. McKenzie, J. and C. van Winkelen, Understanding the Knowledgeable Organization. Thomson Learning, London, 2004.

134. McKenzie, R. B., The Importance of Deviance in Intellectual Development. American Journal of Economics and Sociology 63 (1) 19-49, 2004.

135. Mintzberg, H., Power in and Around Organizations. Theory of Management Policy Series, Prentice Hall, 1983.

136. Mintzberg, H., The Rise and Fall of Strategic Planning. Free Press, New York, 1984.

137. Mintzberg, H., The Organization as Political Arena. Journal of Management Studies 22 (2) 133-155, 1985.

138. Mishra, A., Organizational Responses to Crisis - The Centrality of Trust. Kramer and Tyler eds. Trust in Oranizations. Sage, Thousand Oaks, 261-287, 1996.

139. Morosini, P., Managing Cultural Differences. Effective Strategy and Execution Across Cultures in Global Corporate Alliances. Pergamon, 1998.

140. Morosini, P., S. Shane, and H. Singh, National Cultural Difference and Cross-border Acquisition Performance. Journal of International Business Studies 29 137-158, 1998.

141. Mosher, D. J. and D. Pollack, Managing the Human Dimensions of Mergers and Acquisitions in the Banking Industry. The Bankers Magazine 178 (5) 55, 1995.

142. Nummela, N., S. Saarenketo, and K. Puumalainen, A Global Mindset - A Prerequisite for Successful Internationalization? Canadian Journal of Administration Science 21 (1) 51-64, 2004.

143. O'Reilly III, C. A., and C. Pfeffer, Hidden Value: How Great Companies Achieve Extraordinary Results with Ordinary People. Harvard Business School Press, Boston, 2000.

144. Osterloh, M., Blindes Vertrauen? Facts, November $17^{\text {th }} 60,2005$.

145. Pfeffer, J., The Ambiguity of Leadership. Administrative Science Review 2 (1) 104-112, 1977.

146. Pfeffer, J., Power in Organizations. Pitman, Cambridge, 1981.

147. Pfeffer, J., Managing With Power: Politics and Influence in Organizations. Harvard Business School Press, Boston, 1992.

148. Powell, W. W., Trust-based Forms of Governance. R. M. Kramer and T. R. Tyler, eds. Trust in Organizations. Sage, Thousand Oaks, 51-67, 1996.

149. Pritchett, P. and R. Pound, The Stress of Organizational Change. Pritchett \& Associates, 1996.

150. $\quad$ Prusak, L., The Knowledge Advantage. Strategy \& Leadership 24 6-8, 1996.

151. Rosenberg, H., Minding Mr. Market. CFO Magazine. September $1^{\text {st }}, 1998$.

152. Rüegg-Sturm, J. and L. Achtenhagen, Management-Mode oder unternehmerische Herausforderung: Überlegungen zur Entstehung netzwerkartiger Organisations- und Führungsformen. Die Unternehmung, 54 (1) 322, 2001.

153. Rüegg-Stürm, J. and L. Gritsch, Ungewissheit und Stabilität in Veränderungsprozessen - Zur Bedeutung von Ritualen in tiefgreifenden Veränderungsprozessen von Unternehmen. Discussion Paper No. 42 IfB, University St. Gallen, 2001.

154. Ruigrok, W., A. M. Pettigrew, S. Peck, and R. Whittington. 1999. Corporate restructuring and new forms of organizing: Evidence from Europe. Management Internat. Rev. Wiesbaden. 39 41-64, 1999.

155. Sabel, C., Studied Trust: Building New Forms of Cooperation in a Volatile Economy. R. Swedberg ed. Explorations in Economic Sociology. Sage, New York, 104-144, 1993. 
156. Sachs, W. M., M. Dieleman, J. Fendt, R. Kaminska-Labbé, C. Thomas, and B. McKelvey, Living with Managerial Dilemmas through Irregular Oscillation: Lessons from Coevolution and Complexity Theories. Working Paper, CERAM Sophia Antipolis, 2006.

157. Sales, A. L. and P. H. Mirvis, When Cultures Collide: Issues in Acquisitions. J. R. Kimberly and R. E. Quinn, eds. New Futures: the Challenge of Managing Corporate Transitions. Dow Jones-Irvin, Homewood.107-132, 1984.

158. Sanchez, R. and J. T. Mahoney, Modularity, Flexibility, and Knowledge Management in Product and Organization Design. Strategic Management Journal. 17 63-76, 1996.

159. Schein, E. H., Kurt Lewin's Change Theory in the Field and in the Classroom: Notes Towards a Model of Management Learning. Systems Practice. 9 (1) 27-48, 1996.

160. Schein, E. H., Culture: The Missing Concept in Organizational Studies. Administrative Science Quarterly 41 229-240, 1996a.

161. Schein, E. H., Organizational Learning: What is New? R. A. Rahim, R. T. Golembiewski, and L. E. Pate, eds. Current Topics in Management. Volume 2. Jai Press, Greenwich. 14-26, 1997.

162. Schön, D. A., Beyond the Stable State. Norton, New York, 1971.

163. Schuler, R. S. and S. E. Jackson, HR issues and activities in mergers and acquisitions. European Management Journal 19 (3) 239-253, 2001.

164. Schuler, R. S. and S. E. Jackson, Global strategic alliances: Chapter 2: International Joint Ventures. http://www.swcollege.com/management/jackson/jackson.html 2002 (12.9.2004)

165. Schwager, M. and J. Haar, Erfolgsstrategien für eine dynamische Organisation - Projekt- und Prozessorientierte Unternehmensgestaltung. Freiburg i.Br. 1996.

166. Semler, R., Maverick: The Success Story Behind the World's Most Unusual Workplace. Warner Books, New York.

167. Senge, P. M., The Fifth Discipline. Doubleday Dell, New York, 1990.

168. Senge, P. M., Personal Mastery. G. R. Hickman, ed. Leading Organizations - Perspectives For a New Era. Sage, London. 411-424, 1998.

169. Shaw, R. B., Trust in the Balance - Building Successful Organizations on Results, Integrity and Concern. San Francisco, 1997.

170. Shelton, C. D., Quantum Leaps. Butterworth-Heinemann, Boston, 1999.

171. Shelton, C. D. and J. R. Darling, The Quantum Skills Model in Management: A New Paradigm to Enhance Effective Leadership. Leadership and Organization Development Journal 22 (6) 264-273, 2001.

172. Shelton, C. D., R. F. Hall, and J. R. Darling, When Cultures Collide: The Challenge of Global Integration. European Business Review 15 (5) 312-323, 2003.

173. Sheppard, B. and D. Sherman, The Grammars of Trust: A Model and General Implications. Academy of Management Review 23 (3) 422-438, 1998.

174. Sinetar, M., Building Trust in Corporate Relationships. Organizational Dynamics. 16 (3) $73,1988$.

175. Sirower, M. L., The Synergy Trap: How Companies Lose the Acquisition Game. Free Press, New York, 1998.

176. Sitkin, S. B., Learning Through Failure: The Strategy of Small Losses. M. Cohen and L. Sproull, eds. Organizational Learning. Sage, London. 541-577, 1992.

177. Sitkin, S. B. and A. L. Pablo, The Neglected Importance of Leadership in Mergers and Acquisitions. G. K. Stahl and M. E. Mendenhall, eds. Mergers and Acquisitions: Managing Culture and Human Resources. Stanford University Press. 208-223, 2005.

178. Slowinski, G., Z. E. Rafii, J. C. Tao, L. Gollob, M. W. Sagal, and K. Krishnamurthy, After the Acquisition: Managing Paranoid People in Schizophrenic Organizations. Research-Technology Management 45 (3) 21-32, 2002.

179. Srikanth, K., Acquisition Experience and Value Creation. Proceedings Academy of Management Conference Hawaii, 2005.

180. Stahl, G. K. and S. B. Sitkin, Trust in Mergers and Acquisitions. G. K. Stahl and M. E. Mendenhall, eds. Mergers and Acquisitions: Managing Culture and Human Resources. Stanford University Press. 82-102, 2005.

181. Stanek, M. B., The Need for Global Managers: A Business Necessity. Management Decision. 38 (4) $232-$ 242, 2000. 
182. Starbuck, W. H., A. Greve, and B. Hedberg, Responding to Crises. Journal of Business Administration 9 (2) 111-137, 1978.

183. Strasser, H. and S. Voswinkel, Vertrauen im gesellschaftlichen Wandel. M. Schweer, ed. Interpersonales Vertrauen - Theorien und empirische Befunde. Westdeutscher Verlag, Opladen. 217-236, 1997.

184. Sydow, J., Understanding the Constitution of Interorganizational Trust. Lane and Bachmann, eds. Trust Within and Between Organizations - Conceptual Issues and Empirical Applications. Oxford University Press, New York. 31-63, 2000.

185. Tushman, M. L. and C. A. O’Reilly, Ambidextrous Organizations: Managing Evolutionary and Revolutionary Change. California Management Rev. 38 8-34, 1996.

186. Tushman, M. L. and W. Smith, Organizational Technology. J. A. C. Baum, ed. Companion to Organizations. Blackwell Business, Oxford. 386, 2002.

187. UNCTAD, Cross-Border Mergers and Acquisitions. World Investment Report, 2003.

188. Vaara, E., Post-acquisition Integration as Sensemaking: Glimpses of Ambiguity, Confusion, Hypocrisy and Politicization. Journal of Management Studies 40 (4) 859-894, 2003.

189. Van Bulck, H. E. J. M. L., Global Orientation as a Determinant of International Marketing Decision Making. Unpubl. diss., University of Georgia, 1979.

190. Van Maanen, J., Tales of the Field: On Writing Ethnography. University of Chicago Press, Chicago, 1988.

191. Very, P., M. H. Lubatkin, and R. Calori, A Cross-National Assessment of Acculturative Stress. M. C. Gertsen, A. M. Soderberg, and J. E. Torp, eds. Cultural Dimensions of International Mergers and Acquisitions. De Gruyter, 85-108, 1988.

192. Von Lampe, K. and P. O. Johansen, Criminal Networks and Trust. Proc. $3^{\text {rd }}$ Annual Meeting of the European Society of Criminology, Helsinki, 2003.

193. Von Wartburg, W., Die 'bessere Zukunft' glaubhaft machen. Neue Zürcher Zeitung, November $23^{\text {rd }}, 1999$.

194. Von Wartburg, W., Wahrnehmungsgestaltung als Erfolgsfaktor bei Fusionen. Working paper, Law \& Life Sciences, Basel, 2004.

195. Warglien, M., Intraorganizational Evolution. J. A. C. Baum, ed. Companion to Organizations. Blackwell Business, Oxford. 98-118, 2002.

196. Watson Wyatt, European Results of the Global M\&A Survey. http://www.watsonwyatt.com 2000 (20.9.2004)

197. Watson, T. J., In Search of Management. $2^{\text {nd }}$ Ed. Thomson Learning, 1994.

198. Weaver, G. R., Ethics and Employees: Making the Connection. Academy of Management Executive 18 (2) 121-125, 2004.

199. Webb, E., Trust and Crisis. R. M. Kramer and T. R. Tyler, eds. Trust in Organizations. Sage, Thousand Oaks 261-287, 1996.

200. Weber, M., The Theory of Social and Economic Organization. Macmillan, New York, 1947.

201. Weber, Y. and E. Menipaz, Measuring Cultural Fit in Mergers and Acquisitions. International Journal of Business Performance Management 5 (1) 54-72, 2003.

202. Webster, Webster's New World Dictionary of the English Language: Second College Edition. William Collins, New York, 1987.

203. Weibler, J., Vertrauen und Führung. Klimecki und Remer, eds. Personal als Strategie - mit flexiblen und lernbereiten Human-Ressourcen Kernkompetenzen aufbauen. Luchterhand, Neuwied, 1997.

204. Whitman, M. F., Antecedents of Repatriates' Intent to Leave the Organization: Repatriation Adjustment, Job Satisfaction and Organizational Commitment. Unpublished doctoral dissertation, University of Sarasota, 1999.

205. Williamson, O., The Mechanisms of Governance. Oxford University Press, New York, 1996.

206. Willingham, R., The People Principle: A Revolutionary Redefinition of Leadership. St Martin's, New York, 1997.

207. Zaheer, A., B. McEvily, and V. Perrone, Does Trust Matter? Exploring the Effects of Interorganizational and Interpersonal Trust on Performance. Organization Science 9 (2) 141-159, 1998.

208. Zollo, M. and J. J. Reuer, Experience Spillovers Across Corporate Development Activities. Working Paper, INSEAD and Ohio State Univ.2001. 


\section{ENDNOTE}

1. Managerialist' is defined as viewing organizations from the exclusive perspective of the manager, functional agent of an administered system, whose purpose it is to ensure the: "...survival, growth, profitability of the organization" (Boje, 2002) and to "...satisfy the immediate demands of shareholders, customers and (to some extent) workers" (Alvesson and Willmott, 1996:161). Managerialist ideology became apparent in early 1900, when corporate capitalism superseded family (entrepreneurial) capitalism. Max Weber (1947) infused managerialism with a masculine and paternalistic ethic (Martin and Knopoff, 1995). This ethical connotation has meanwhile been challenged by organizational behavior researchers (Gephart, 1978, 1992). Marcuse (1964) views managerialism as being decidedly functionalist, as it signifies the shift from the owner to the professional manager to: "...legitimate the control of individuals, societies and their organizations in the interest of capital" (Davis, 1997). To understand the distinction between owners and corporate managers see also Berle and Means (1933), Chandler (1977) and Williamson (1996). In managerialism executives are seen as endowed with a responsibility to balance the interests of all stakeholders and, by being responsible to everyone, end up accountable to hardly anyone but themselves (Enteman 1993).

\section{NOTES}


NOTES 
i 'Managerialist' is defined as viewing organizations from the exclusive perspective of the manager, functional agent of an administered system, whose purpose it is to ensure the: "...survival, growth, profitability of the organization" (Boje, 2002) and to "...satisfy the immediate demands of shareholders, customers and (to some extent) workers" (Alvesson and Willmott, 1996:161). Managerialist ideology became apparent in early 1900, when corporate capitalism superseded family (entrepreneurial) capitalism. Max Weber (1947) infused managerialism with a masculine and paternalistic ethic (Martin and Knopoff, 1995). This ethical connotation has meanwhile been challenged by organizational behavior researchers (Gephart, 1978, 1992). Marcuse (1964) views managerialism as being decidedly functionalist, as it signifies the shift from the owner to the professional manager to: "...legitimate the control of individuals, societies and their organizations in the interest of capital" (Davis, 1997). To understand the distinction between owners and corporate managers see also Berle and Means (1933), Chandler (1977) and Williamson (1996). In managerialism executives are seen as endowed with a responsibility to balance the interests of all stakeholders and, by being responsible to everyone, end up accountable to hardly anyone but themselves (Enteman 1993). 